\title{
Bioassay-guided Isolation of New Antitumor Agent from Ficus faveolata (Wall. ex Miq.)
}

Ala Ud Din ${ }^{1 *}$, Ghias Uddin², Nusrat Hussain ${ }^{3}$, Ajmal Khan ${ }^{3}$, Inamullah Khan ${ }^{4}$, Anwar Ali Shad ${ }^{5}$ and Muhammad Iqbal Choudhary ${ }^{3}$

${ }^{1}$ Deparment of Chemistry, Bacha Khan University Charsadda 24420, Pakistan

${ }^{2}$ Center for Phytomedicine and Medicinal Organic Chemistry, Institute of Chemical Sciences, University of Peshawar, Pakistan

${ }^{3} \mathrm{HEJ}$ Research Institute of Chemistry, International Center for Chemical and Biological Sciences, University of Karachi, Pakistan

${ }^{4}$ Department of Pharmacy, University of Peshawar, Pakistan

${ }^{5}$ Department of Agricultural Chemistry, KPK Agricultural University, Peshawar, Pakistan

\begin{abstract}
Ficus species have been used in both Ayurvedic and Traditional Chinese Medicine (TCM); however the medicinal uses of these species are widely found and originated in Middle East. The phytochemical study of Ficus foveolata was under taken with small scale extraction of stem $(300 \mathrm{~g})$ for cytotoxic screening and dereplication purpose. The crude methanolic extract of Ficus was partitioned into different fractions of hexane, dichloromethane and methanol. All the five fractions FA, FB, FC, FD and FE were screened for their anti-proliferative effect in the disk diffusion assay (In vitro) against six cancer cell lines. The bioassay-guided isolation of a new antitumor agent (Ficusonolide; 3 $\alpha$-hydroxylean-12-en-29, 19a-olide (1)) was carried out from the methanolic extract (FB) of Ficus faveolata. Its structure was elucidated on the basis of extensive spectroscopic techniques (IR, MS and NMR). The pure compound 1 was evaluated against twelve cell cancer lines for the determination of its antiproliferative potency. In disk diffusion assay the dichloromethane fraction (FB) showed excellent activity at very low concentration. The compound 1 exhibited strong and selective activity against two cancer cell lines: $\mathrm{H} 116$ (Human colon adenocarcinoma) and $\mathrm{H} 125$ (Human lung adenocarcinoma) with the $\mathrm{IC}_{50}=7.8 \mu \mathrm{g} / \mathrm{ml}$ and $11.0 \mu \mathrm{g} /$ $\mathrm{ml}$ respectively. The selectivity and potency of the pure compound $\mathbf{1}$ was in concordance with the activity profile of the fraction FB and ethno-medicinal uses of this plant. This small project on local medicinal plants has opened new vista for future research work on indigenous medicinal plants. The compound 1 can be used a template compound for further studies, as a chemotherapeutic agents against cancer.
\end{abstract}

Keywords: Moraceae; Ficus foveolata; Stem; Cytotoxicity; Crude fractions; Ficusonolide

\section{Introduction}

Ficus (Fig genus) is one of the largest and most important genus of the family Moraceae (mulberry). It consists of more than 800 species with habitats in lowland rainforest of tropical region [1]. Ficus species have been used in both Ayurvedic and Traditional Chinese Medicine (TCM); however the medicinal uses of these species are widely found and originated in Middle East [2]. The different parts (roots, stem, leave, fruits and latex) of Ficus spp. have shown anti-diabetic, anticancer and anti-inflammatory activities [3]. The phytochemical investigation of these species resulted into the isolation of different classes of bioactive secondary metabolites such as phenanthroindolizidine alkaloids, coumarins, multiple flavonoids, triterpenoids, different triacylglycerols and a number of volatile compounds [3-6].

The Ficus foveolata is a scandent climber shrub distributed in most of the Asia [7]. In Pakistan this plant is widely distributed in northern regions (Khyber Pukhtoonkhwa) of Pakistan, where it is locally called 'baat anzar' and has wide uses in folk medicines. According to our survey the powdered stem of Ficus foveolata is mixed with other local medicinal plants for the treatment of a cancer type locally called 'nasoor' which convinced us for future phytochemical investigation of this plant. Furthermore the Ficus foveolata has also been reported to be used in traditional medicines in the rest of the world for different ailment and disorders. For example, in Nepal its bark is used as lactating agent for milk secretion [8] and in Thailand, people use it as a tonic in a number of ways [9]. Literature survey showed only two recently published articles on the phytochemical constituents of this plant which reported the isolation of $(1 E, 22 E)$-1,22-docosanediol diferulate [10] and two new eudesmane-type sesquiterpenes [11]. In the present study, we explored the selective anti-tumor potential of crude methanolic fractions and pure compound $3 \alpha$-hydroxylean-12en-29,19 $\alpha$-olide (1), along with isolation and characterization studies of compound 1 .

The phytochemical study of Ficus foveolata was under taken with small scale extraction of stem (300 g) for cytotoxic screening and dereplication purpose. The crude methanolic extract was partitioned into different fractions of hexane, dichloromethane and methanol. All the five fractions FA, FB, FC, FD and FE were screened for their antiproliferative effect by using the disk diffusion assay (In vitro). Initial stimulus for further research on dichloromethane fraction (FB) was its impressive activity against twelve different cancer cell lines (assayed at U.S. Josephine Ford Cancer Center). The LC-MS profile of the FB fraction was developed for dereplication purpose which exhibited few peaks with one major at $m / z 454$. The known data was dereplicated by comparing the UV and MS data with reported compounds in Dictionary of Natural Product (DNP). A number of hits were observed in DNP for the major peak at $m / z 454$ however due to interesting ${ }^{1} \mathrm{H}$ NMR

*Corresponding author: Ala Ud Din, Deparment of Chemistry, Bacha Khan University Charsadda 24420, Pakistan, Tel: +92-939540156; E-mail: allauddin77@ yahoo.com; allauddin4763@gmail.com

Received October 03, 2013; Accepted November 18, 2013; Published November 23, 2013

Citation: Din AU, Uddin G, Hussain N, Khan A, Khan I, et al. (2013) Bioassayguided Isolation of New Antitumor Agent from Ficus faveolata (Wall. ex Miq.). J Cancer Sci Ther 5: 404-408. doi:10.4172/1948-5956.1000233

Copyright: ( 2013 Din AU, et al. This is an open-access article distributed under the terms of the Creative Commons Attribution License, which permits unrestricted use, distribution, and reproduction in any medium, provided the original author and source are credited. 
Citation: Din AU, Uddin G, Hussain N, Khan A, Khan I, et al. (2013) Bioassay-guided Isolation of New Antitumor Agent from Ficus faveolata (Wall. ex Miq.). J Cancer Sci Ther 5: 404-408. doi:10.4172/1948-5956.1000233

spectrum the peak was selected for purification and characterization. Large scale extraction of Ficus foveolata stem (13 kg) resulted into the isolation of $3 \alpha$-hydroxylean-12-en-29,19 $\alpha$-olide; Ficusonolide (1, $\mathrm{C}_{30} \mathrm{H}_{46} \mathrm{O}_{3}, m / z$ 454) (Figure 1).

\section{Materials and Methods}

\section{General}

Melting point was determined using Buchi 535 digital device. Optical rotation was taken on Jasco-P2000 digital polarimeter in $\mathrm{MeOH}$ at room temperature while the IR $(\mathrm{KBr})$ data was recorded on Bruker VECTOR 22 spectrophotometer; $v_{\max }$ in $\mathrm{cm}^{-1}$. UV data was taken from 996 photodiode array detector connected to analytical HPLC-MS instrument. ${ }^{1} \mathrm{H}$ NMR $\left(300 \mathrm{MHz}, \mathrm{C}_{5} \mathrm{D}_{5} \mathrm{~N}\right)$ and ${ }^{13} \mathrm{C} \mathrm{NMR}$ $\left(125 \mathrm{MHz}, \mathrm{C}_{5} \mathrm{D}_{5} \mathrm{~N}\right)$ spectra were recorded on Bruker instrument, the chemical shift value was presented in $\delta$ (ppm) and coupling constant $(J)$ in Hz. For the purity of isolates and chemical profile of fraction FB analytical HPLC $\left(\mathrm{MeOH} / \mathrm{H}_{2} \mathrm{O}\right.$ with $\left.0.1 \% \mathrm{FA}\right)$ equipped with Phenomenex Luna column C18 RP $(5 \mu \mathrm{m}, 150 \times 4.6)$, Sedex 55 ELS detector (ELSD), 996 photodiode array detector and ESI-TOF-MS $(+)$ was used. Phenomenex $5 \mu$ m Luna $C_{18}$ RP column $(250 \times 10)$ was used for preparative HPLC. ESI-MS and HRESIMS were recorded on mariner ESI-TOF-MS instrument.

\section{Plant material}

The stem of Ficus faveolata was collected from district Buner, Khyber Pukhtoonkhwa, Pakistan during the month of July 2007. The plant was identified by taxonomist Mr. Ambara Khan and voucher specimen (Bot.15077) was deposited in the Herbarium of Department of Botany, University of Peshawar, Pakistan.

\section{Extraction and isolation}

The air dried stem (13 kg) of Ficus faveolata were repeatedly extracted (X3) with $80 \% \mathrm{MeOH} / \mathrm{H}_{2} \mathrm{O}$ at room temperature after every $24 \mathrm{hrs}$. The combined extract was concentrated under vacuum at $40^{\circ} \mathrm{C}$, to obtain brownish thick syrup that constituted the crude aqueous methanolic extract $(100 \mathrm{~g})$ which was first partitioned into five fractions: FA, FB, FC, FD and FE on polarity basis. The suspended crude extract in water was defatted (X3) with petroleum ether affording fraction FA (35 g). The polarity of suspension was change to $10 \% \mathrm{MeOH} / \mathrm{H}_{2} \mathrm{O}$ followed by extraction with dichloromethane (DCM) to obtain DCM soluble fraction $\mathrm{FB}(11.5 \mathrm{~g})$. By addition of $\mathrm{MeOH}(1.8 \mathrm{~L})$ the polarity of aqueous suspension was again changed to $50 \% \mathrm{MeOH} / \mathrm{H}_{2} \mathrm{O}$ and extracted with DCM to obtain fraction FC $(7 \mathrm{~g})$. Finally the polarity of the aqueous layer was changed to approximately $70 \% \mathrm{MeOH} / \mathrm{H}_{2} \mathrm{O}$ which was further extracted with DCM to get DCM soluble fraction FD $(10 \mathrm{~g})$, while the remaining DCM insoluble phase was get concentrated under vacuum to get methanolic fraction (FE).

After all the five fractions were screened for cytotoxic activity against six cancer cell lines, the LCMS profiles of fraction FB was developed. Fraction FB (11.5 g) was subjected to HPLC (Phenomenex Luna column $\mathrm{C}_{18} \mathrm{RP}(5 \mu \mathrm{m}, 150 \times 4.6 ; 0.1 \%$ acidic (formic acid) gradient solvent system (10-100 $\mathrm{MeCN} / \mathrm{H}_{2} \mathrm{O}$ in 30 minutes) in order to purified the selected peak, which resulted into the isolation of compounds 1 (14 mg).

\section{Physical data of compound 1}

White amorphous powder with molecular formula $\mathrm{C}_{30} \mathrm{H}_{46} \mathrm{O}_{3}(14$ $\mathrm{mg}$ ); mp $177^{\circ} \mathrm{C} ;[\alpha]_{\mathrm{D}}^{29.7} 117$ (c 0.1, MeOH); IRfilm (KBr): 3490, 3050,
$1748 \mathrm{~cm}^{-1}$; EIMS m/z (rel. int.\%): 246.1 (100), 190 (50), 207 (40), $454[\mathrm{M}]^{+}$(17); HRESIMS $m / z 455.3456\left[\mathrm{M}^{+}+\mathrm{H}\right]$ (calcd. 455.3447 for $\mathrm{C}_{30} \mathrm{H}_{46} \mathrm{O}_{3}$ ); for ${ }^{1} \mathrm{H}$ and ${ }^{13} \mathrm{C}$ NMR Table 1.

\section{Anti-proliferative in vitro disk diffusion assay}

The Disk Diffusion Assay (DDA) was performed in Josephine Ford Cancer Center (JFCC) [12]. For determination of cytotoxic potency and solid tumor selectivity, the crude fractions (FA, FB, FC, FD and $\mathrm{FE}$ ) and pure compound $\mathbf{1}$ (isolated from FB fraction) were screened against six and twelve cancer cell lines respectively. Selectivity is the measure of differential inhibition of solid tumor cell line against normal or leukemia cell line ( 200 zone units $=6.5 \mathrm{~mm}$ ) in the disk diffusion assay, while positive activity is define as zone of inhibition greater 250 zone units. After dissolution in DMSO, the samples were pipetted onto a paper disk and then applied to an agar plate which is seeded with a particular cell line. Then the agar plates were incubated for cell growth, and the samples activity was analyzed by the size of zone of inhibition (in zone units or $\mathrm{mm}$ ) of cell growth on agar plate. For determination of $\mathrm{IC}_{50}$ value, human tumor cells were seeded in concentration of $5 \times$ $10^{4}$ cells in T25 tissue culture flasks (Falcon Plastics, NJ, USA) with 5 mL media RPMI 1640 (Cellgro, Virginia) supplemented with 15\% BCS (Hyclone, Utah), 5\% Penicillin/Streptomycin and 5\% Glutamine. After three days incubation (cells in logarithmic growth phase; $5 \times 10^{5}$ cells/ flask), test compound was added to the flasks to achieve concentrations ranging from $10^{1}$ to $10^{-5} \mu \mathrm{g} / \mathrm{mL}$. The cultured flasks were then incubated for seventy-two hours, then the cells were washed, trypsinized, spun down and counted for both viable and dead cells using 0.08\% trypan blue (Gibco, Maryland). The number of viable cells number was plotted as a function of concentration and the $\mathrm{IC}_{50}$ value determined by interpolation [13]. Each point was carried out in duplicate and a standard deviation determined.

\section{Results and Discussion}

Compound 1 (Ficusonolide) was isolated as white amorphous powder and its structure elucidation was commenced by developing molecular formula $\mathrm{C}_{30} \mathrm{H}_{46} \mathrm{O}_{3}$ via high resolution ESIMS which showed molecular ion peak at $\mathrm{m} / z 455.3456\left[\mathrm{M}+\mathrm{H}^{+}\right]$(calcd. for $\mathrm{C}_{30} \mathrm{H}_{46} \mathrm{O}_{3}+\mathrm{H}^{+}=455.3447$ ). Molecular formula $\mathrm{C}_{30} \mathrm{H}_{46} \mathrm{O}_{3}$ of $\mathbf{1}$ exhibited

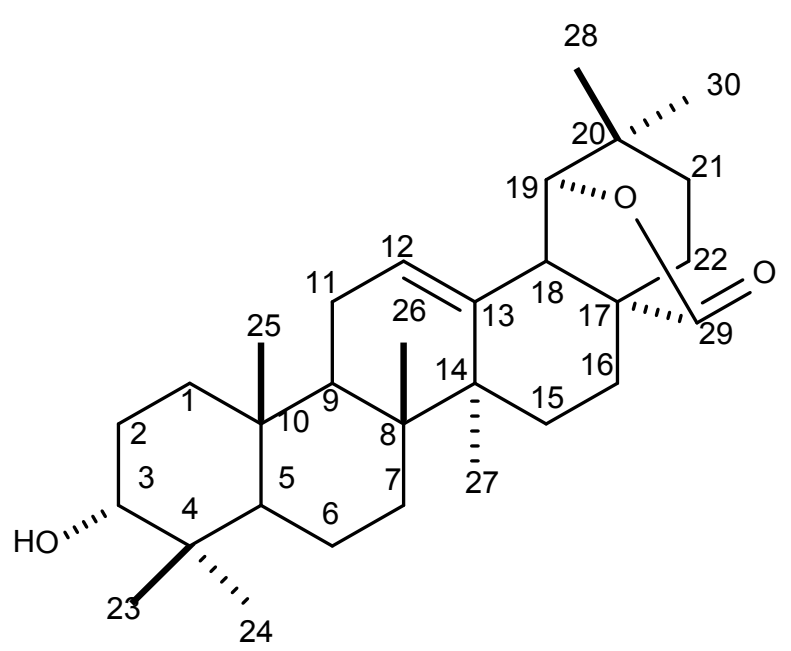

Figure 1: The structure of compound 1 isolated from the stem of Ficus foveolata. 
Citation: Din AU, Uddin G, Hussain N, Khan A, Khan I, et al. (2013) Bioassay-guided Isolation of New Antitumor Agent from Ficus faveolata (Wall. ex Miq.). J Cancer Sci Ther 5: 404-408. doi:10.4172/1948-5956.1000233

\begin{tabular}{|c|c|c|c|}
\hline C. No & $\delta C$ & $\delta \mathrm{H} / \mathrm{ppm}$ (multi, integral, J/Hz) & HMBC \\
\hline \multirow[t]{2}{*}{1} & 33.8 & $2.23(1 \mathrm{H}, \mathrm{s})$ & C3,C5 \\
\hline & & $1.82(1 \mathrm{H}, m)$ & $\mathrm{C} 4, \mathrm{C} 10$ \\
\hline \multirow[t]{2}{*}{2} & 25.6 & $2.01(1 \mathrm{H}, m)$ & \\
\hline & & $1.18(1 \mathrm{H}, m)$ & \\
\hline 3 & 77.9 & $3.43(\mathrm{IH}, d d, 10.5$ and 4.0$)$ & \\
\hline 4 & 37.3 & & \\
\hline 5 & 55.7 & $2.03(1 \mathrm{H}, m)$ & $\mathrm{C} 8, \mathrm{C} 10$ \\
\hline \multirow[t]{2}{*}{6} & 18.7 & $1.65(1 \mathrm{H}, d, 3.6)$ & \\
\hline & & $1.45(1 \mathrm{H}, d, 3.0)$ & C5, C9, C14 \\
\hline \multirow[t]{2}{*}{7} & 33.4 & $1.46(1 \mathrm{H}, m)$ & \\
\hline & & $1.34(1 \mathrm{H}, m)$ & \\
\hline 8 & 39.6 & & \\
\hline 9 & 47.8 & $1.57(1 \mathrm{H}, m)$ & \\
\hline 10 & 35.4 & & \\
\hline \multirow[t]{2}{*}{11} & 23.7 & $1.84(1 \mathrm{H}, m)$ & $\mathrm{C} 8, \mathrm{C} 13$ \\
\hline & & $1.20(1 \mathrm{H}, m)$ & \\
\hline 12 & 124.9 & & \\
\hline 13 & 140.5 & & \\
\hline 14 & 39.5 & & \\
\hline 15 & 28.1 & $1.80(1 \mathrm{H}, m)$ & \\
\hline \multirow[t]{2}{*}{16} & 24.6 & $0.99(1 \mathrm{H}, m)$ & C14, C18 \\
\hline & & $1.57(1 \mathrm{H}, m)$ & \\
\hline 17 & 42.6 & & \\
\hline 18 & 43.3 & $0.85(1 \mathrm{H}, s)$ & $\mathrm{C} 14, \mathrm{C} 16$ \\
\hline 19 & 83.1 & $4.13(1 \mathrm{H}, d, 5.4)$ & \\
\hline 20 & 39.3 & & \\
\hline \multirow[t]{2}{*}{21} & 40.3 & $1.95(1 \mathrm{H}, m)$ & \\
\hline & & $1.47(1 \mathrm{H}, m)$ & \\
\hline \multirow[t]{2}{*}{22} & 39.1 & $1.63(1 \mathrm{H}, m)$ & \\
\hline & & $1.52(1 \mathrm{H}, m)$ & \\
\hline 23 & 16.6 & $1.04(3 \mathrm{H}, s)$ & $\mathrm{C} 3, \mathrm{C} 5$ \\
\hline 24 & 28.7 & $1.22(3 \mathrm{H}, s)$ & $\mathrm{C} 3, \mathrm{C} 5$ \\
\hline 25 & 15.8 & $0.94(3 \mathrm{H}, s)$ & $\mathrm{C} 1, \mathrm{C} 9$ \\
\hline 26 & 21.2 & $1.21(3 \mathrm{H}, s)$ & C9, C14 \\
\hline 27 & 24.0 & $1.07(3 \mathrm{H}, s)$ & $\mathrm{C} 7, \mathrm{C} 15$ \\
\hline 28 & 24.8 & $0.80(3 \mathrm{H}, s)$ & $\mathrm{C} 16, \mathrm{C} 22$ \\
\hline 29 & 182.3 & & \\
\hline 30 & 17.1 & $0.90(3 \mathrm{H}, s)$ & $\mathrm{C} 19, \mathrm{C} 21, \mathrm{C} 29$ \\
\hline
\end{tabular}

Table 1: ${ }^{1} \mathrm{H}$ and ${ }^{13} \mathrm{C}$ NMR of ficusonolide (1) $\left(500 \mathrm{MHz}\left({ }^{1} \mathrm{H}\right.\right.$ NMR) and $125 \mathrm{MHz}$ $\left({ }^{13} \mathrm{C}\right), \mathrm{C}_{5} \mathrm{D}_{5} \mathrm{~N}, \delta$ in ppm, $J$ in $\left.\mathrm{Hz}\right)$

8 degree of unsaturations and its IR spectrum displayed strong absorption bands at 3490, 2945, 1748 and $1377 \mathrm{~cm}^{-1}$, indicating the presence of hydroxyl, C-H saturated ester carbonyl and gem-dimethyl functionalities respectively. The ${ }^{13} \mathrm{C}$ NMR spectrum of $\mathbf{1}$ indicated 30 carbon atoms including seven methyls, nine methylenes, six mithines and eight quaternary on the basis of DEPT spectrum analysis (Table 1). The ${ }^{1} \mathrm{H}$ and ${ }^{13} \mathrm{C}$ NMR spectra displayed signals which were assigned to eight methyl's $\left[\delta_{\mathrm{C}} 16.6 / \delta_{\mathrm{H}} 1.04(\mathrm{~s}, \mathrm{Me}-23), \delta_{\mathrm{C}} 28.7 / \delta_{\mathrm{H}} 1.22(\mathrm{~s}, \mathrm{Me}-24)\right.$, $\delta_{\mathrm{C}} 15.8 / \delta_{\mathrm{H}} 0.94(\mathrm{~s}, \mathrm{Me}-25), \delta_{\mathrm{C}} 21.2 / \delta_{\mathrm{H}} 1.21(\mathrm{~s}, \mathrm{Me}-26), \delta_{\mathrm{C}} 24.0 / \delta_{\mathrm{H}} 1.07$ (s, Me-27), $\delta_{\mathrm{C}} 24.8 / \delta_{\mathrm{H}} 0.80(\mathrm{~s}, \mathrm{Me}-28)$ and $\left.\delta_{\mathrm{C}} 17.1 / \delta_{\mathrm{H}} 0.90(\mathrm{~s}, \mathrm{Me}-30)\right]$. The two oxymethine signals at $\delta_{\mathrm{H}} 3.43(1 \mathrm{H}, \mathrm{dd}, J=10.5,4.0 \mathrm{~Hz})$ and $\delta_{\mathrm{H}}$ $4.13(1 \mathrm{H}, \mathrm{d}, J=5.4 \mathrm{~Hz})$ coupled with $\delta_{\mathrm{C}} 77.9$ and $\delta_{\mathrm{C}} 83.1$ in the HSQC respectively, and a vinylic methine at $\delta_{\mathrm{H}} 5.30(1 \mathrm{H}, \mathrm{t}, J=3.6 \mathrm{~Hz})$ show strong correlation with carbon at $\delta_{\mathrm{C}} 124.9$ in the HSQC spectrum and carbon atoms at $\delta_{\mathrm{C}} 47.8, \delta_{\mathrm{C}} 39.5$ and $\delta_{\mathrm{C}} 43.3$ in $\mathrm{HMBC}$ spectrum.

The ${ }^{13} \mathrm{C}$ NMR indicated the presence of ester group $\delta_{C} 182.3(\mathrm{C}-29)$ and a trisubstituted double bond $\delta_{\mathrm{C}} 124.9(\mathrm{C}-12)$ and $\delta_{\mathrm{C}} 140.5(\mathrm{C}-13)$. These characteristic spectral data suggested the presence of oleane- 12-en skeleton in compound 1 [13]. Furthermore the mass spectrum showed standard retro-Diel Alder fragmentation $(\mathrm{m} / \mathrm{z} 207$ and 246) (Figure 2c), indicating the presence of lactone ring at ring $\mathrm{D}$ and/or E [14]. The presence of one carbonyl group, one olefinic bond and six rings in compound $\mathbf{1}$ can fully satisfied eight degree of unsaturations evident in the molecular formula $\mathrm{C}_{30} \mathrm{H}_{46} \mathrm{O}_{3}$. All these spectral data suggested that compound 1 was olean-12-en type triterpene with a secondary hydroxyl group and lactone ring. However the position and spatial orientation of hydroxyl group and lactone ring were yet to have determined.

The attachment of hydroxyl group at position C-3 and lactone ring on ring $\mathrm{E}$ (between $\mathrm{C}-17$ and $\mathrm{C}-19$ ) were made by $2 \mathrm{D}$ correlation spectra (COSY and HMBC) and mass fragmentation pattern (Figures $2 \mathrm{a}-2 \mathrm{c})$. The connection of downfield resonating proton at $\delta_{\mathrm{H}} 3.43(\mathrm{t}$, $J=3.0 \mathrm{~Hz} ; \mathrm{H}-3)$ with carbon at $\delta_{\mathrm{C}} 77.9(\mathrm{C}-3)$ was observed in the HSQC correlation spectrum, indicating the attachment of a hydroxyl group at C-3. This assignment was confirmed by HMBC correlations of Me-23 $\left(\delta_{\mathrm{H}} 1.02\right)$ and Me-24 $\left(\delta_{\mathrm{H}} 1.22\right)$ with C-3 $\left(\delta_{\mathrm{C}} 79.7\right), \mathrm{C}-4\left(\delta_{\mathrm{C}} 38.0\right)$ and C-5 $\left(\delta_{\mathrm{C}} 48.0\right)$, while long range $\mathrm{HMBC}$ correlations were observed for protons of C-2 $(\mathrm{Ha}, \mathrm{m}, 2.01, \mathrm{Hb}, \mathrm{m}, 1.18)$ with $\mathrm{C}-3\left(\delta_{\mathrm{C}} 79.7\right), \mathrm{C}-5\left(\delta_{\mathrm{C}}\right.$ $48.0)$ and $\mathrm{C}-25\left(\delta_{\mathrm{C}} 16.1\right)$. The attachment of hydroxyl group at $\mathrm{C}-3$ was further supported by COSY correlations of proton at $\delta 2.01(\mathrm{~m}, \mathrm{H}-2)$ with $\delta 3.43$ (dd, $J=10.5,4.0 \mathrm{~Hz} ; \mathrm{H}-3$ ) and $\delta 2.23$. (m, H-1).

Mass fragmentation of compound $\mathbf{1}$ indicated the presence of lactone ring in either ring $\mathrm{D}$ and/or $\mathrm{E}$, however the exact attachment of lactone ring to ring $\mathrm{E}$ (between $\mathrm{C}-17$ and $\mathrm{C}-19$ ) was made by COSY and HMBC correlations (Figures 2a-2c). HMBC spectrum exhibited long range correlations of proton at $\delta_{\mathrm{H}} 4.13(\mathrm{~d}, J=5.4 \mathrm{~Hz} ; \mathrm{H}-19)$ with carbons at $\delta_{\mathrm{C}} 42.6,24.8,182.3$ and 17.1, while proton at $\delta_{\mathrm{H}} 1.95(\mathrm{~m}, \mathrm{H}-21)$ with carbons resonating at $\delta_{\mathrm{C}} 42.6,83.1$ and 17.1. COSY spectrum showed correlations of proton at $\delta_{\mathrm{H}} 4.13(\mathrm{~d}, J=5.4 \mathrm{~Hz} ; \mathrm{H}-19)$ with $\delta_{\mathrm{H}} 0.85$ (brd. $\mathrm{s} ; \mathrm{H}-18)$ and $\delta_{\mathrm{H}} 0.80$ (s, Me-28) (Figures 2a-2c).

The relative configuration of hydroxyl group at C-3 was determined

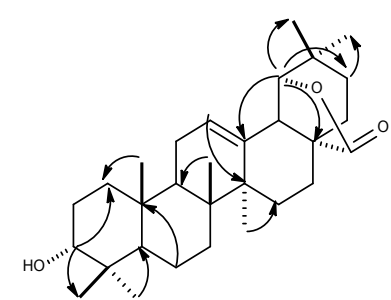

(a)

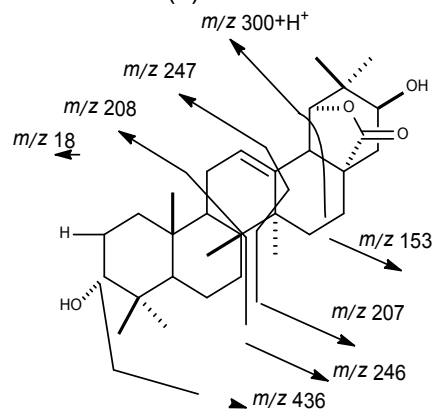

(c)

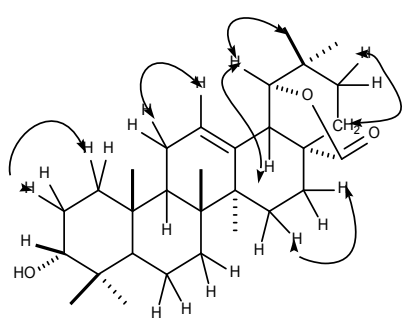

(b)

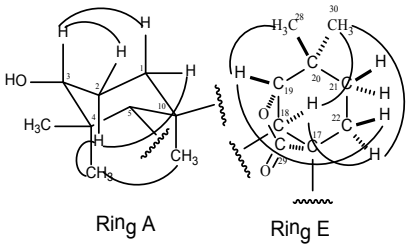

(d)
Figure 2: (a) Important HMBC correlations, (b) COSY correlations, (c) mass fragmentation pattern and (d) NOESY correlations. 
Citation: Din AU, Uddin G, Hussain N, Khan A, Khan I, et al. (2013) Bioassay-guided Isolation of New Antitumor Agent from Ficus faveolata (Wall. ex Miq.). J Cancer Sci Ther 5: 404-408. doi:10.4172/1948-5956.1000233

by splitting pattern, coupling constant and NOESY correlations. The carbinol proton in compound $\mathbf{1}$ appearing as doublet of doublet with large coupling constant at $\delta 3.43(\mathrm{dd}, J=10.5,4.0 \mathrm{~Hz} ; \mathrm{H}-3)$ which revealed the equatorial positions of hydroxyl group at C-3 instead of triplet for axial position. The NOESY spectrum showed axial-equatorial correlations of proton $\delta 3.43(\mathrm{H}-3)$ with $\delta 1.18(\alpha \mathrm{H}-2)$ and axial-axial correlation with $\delta 2.23(\beta \mathrm{H}-1)$, similarly proton $\delta 2.01(\beta \mathrm{H}-2)$ displayed correlations with $\delta 1.82(\alpha \mathrm{H}-1)$ and $\delta 1.04(\mathrm{Me}-23)$ (Figure $2 \mathrm{~d})$ further verified that hydroxyl group at $\mathrm{C}-3$ was equatorially oriented.

The relative stereochemistry of rings $\mathrm{E}$ and lactone were developed on the basis of NOESY spectrum and protons splitting pattern. Proton resonated at $\delta_{H} 4.13(J=5.4 \mathrm{~Hz} ; \mathrm{H}-19)$ appeared as doublet indicating its axial position instead of equatorial which appeared as doublet of doublet in 3-epiabruslactone [14]. The NOESY spectrum showed correlations of proton at $\delta_{\mathrm{H}} 4.13(\mathrm{H}-19)$ with $\delta_{\mathrm{H}} 0.90(\alpha \mathrm{Me}-30)$ and $\delta_{\mathrm{H}} 1.63(\beta \mathrm{H}-22)$, and proton at $\delta_{\mathrm{H}} 0.85(\mathrm{H}-18)$ with $\delta_{\mathrm{H}} 0.85(\alpha \mathrm{H}-$ $22)$ and $\delta_{\mathrm{H}} 0.80(\beta \mathrm{Me}-28)$ (Figure $\left.2 \mathrm{~d}\right)$. On the basis of spectral data and comparison with spectral data of related compounds [15], the structure of 1 was elucidated as $3 \alpha$-hydroxylean-12-en-29,19 $\alpha$-olide (Ficusonolide), which to the best of our knowledge is a new compound.

In the preliminary screening, all the five crude fractions (FA-FE) were screened for their cytotoxicity against six cancer cell lines on different dilution (Table 2). All the fractions exhibited variable degree of cytotoxic activity. Initial results indicated that fractions (FA and FC) did not showed reasonable cytotoxic activity compared to FB, FD and $\mathrm{FE}$ fractions. For further confirmation, the fractions FB, FD and FE were also evaluated on high dilution. The fraction FD was moderatively active with zone of inhibition of 750, 350, 550, 700 and 750 (200 zone units $=6.5 \mathrm{~mm}$ ) for L1210, Colon38, CFU-GM, H-116 and H-125 cell line respectively. The fraction FD were also checked on 1/4 dilution, where at low concentration the activity declined approximately at 300 zone of inhibition. The fraction FE was found to show significant activity with zone of inhibition 900 against Murine lyphocytic leukemia. At low concentrations (dilution of $1 / 4$ and 1/16), the FE exhibited reasonable activity with zone of inhibition 800 and the activity was declined to

\begin{tabular}{|c|c|c|c|c|c|c|c|}
\hline Fract $^{\mathbf{a}}$ & Dil $^{\mathbf{b}}$ & L1210 & Colon38 & CFU-GM & H-116 & H-125 & CEM \\
\hline DMSO & 0 & 0 & 0 & 0 & 0 & 0 & 0 \\
\hline FA & & 550 & 300 & 300 & 400 & 600 & 500 \\
\hline FB & & $>1000$ & & & & & \\
\hline$"$ & $1 / 4$ & $>1000$ & & & & & \\
\hline$"$ & $1 / 16$ & & $>1000$ & & & & \\
\hline$"$ & $1 / 64$ & & & & $>1000$ & & \\
\hline$"$ & $1 / 256$ & $>1000$ & 500 & & & 1000 & \\
\hline$"$ & $1 / 1024$ & & & 700 & 900 & $>1000$ & 650 \\
\hline$"$ & $1 / 4096$ & & & 800 & 700 & $>1000$ & 500 \\
\hline$"$ & $1 / 16384$ & & & 450 & & 850 & 350 \\
\hline FC & & 350 & 350 & 300 & 200 & 300 & 450 \\
\hline FD & & 750 & 350 & 550 & 700 & 750 & \\
\hline & $1 / 4$ & 450 & 100 & & & & \\
\hline FE & & 900 & & & & & \\
\hline & $1 / 4$ & 800 & & & & & \\
\hline & $1 / 16$ & 800 & 350 & 450 & & & \\
\hline & $1 / 64$ & & & 550 & 400 & 450 & 550 \\
\hline
\end{tabular}

aFract=Crude fractions, ${ }^{b}$ Dil=Dilution, L1210 (Murine lyphocytic leukemia), Colon38 (Murine colon adrenocarcinoma), CFU-GM (Murine granulocyte macrophage colony formy unit), $\mathrm{H}-116$ (Human colon adrenocarcinoma), $\mathrm{H}-125$ (Human lung adrenocarcinoma) and CEM (Humane leukemic lymphoid)

Table 2: In vitro disk diffusion assay for crude fractions (FA-FE).

\begin{tabular}{|l|c|}
\hline Cancer cell line & IC $_{50}$ in $\boldsymbol{\mu g} / \mathbf{m L}$ \\
\hline L1210 (Murine lyphocytic leukemia) & $>100$ \\
\hline Colon38 (Murine colon adrenocarcinoma) & $>100$ \\
\hline CFU-GM (Murine granulocyte macrophage colony formy unit) & $>100$ \\
\hline H116 (Human colon adrenocarcinoma) & 7.8 \\
\hline H125 (Human lung adrenocarcinoma) & 11.0 \\
\hline MCF-7 (Hormone responsive breast cancer) & $>100$ \\
\hline LNCaP (Androgen sensitive prostate cancer) & $>100$ \\
\hline OVC-5 (Ovarian cancer) & $>100$ \\
\hline U251N (Glioblastoma) & $>100$ \\
\hline MDA (Melanoma) & $>100$ \\
\hline PANC-1 (Murine pancreatic solid tumor) & $>100$ \\
\hline CEM (Humane leukemic lymphoid) & $>100$ \\
\hline
\end{tabular}

Table 3: Anti-proliferative activity $\left(\mathrm{IC}_{50}\right.$ in $\left.\mu \mathrm{g} / \mathrm{mL}\right)$ of Ficusonolide (1).

the zone of inhibition approximately 550 at dilution of $1 / 64$ for all cell lines. The fraction FB was found to be most significantly active among all five fractions having zone of inhibition more than 1000 for all cell lines. Interestingly the fraction FB was found consistently active even upto low dilution (1/64 dilution) exhibiting zone of inhibition more than 1000. The FB showed significant inhibition at dilution 1/256 with zone of inhibition more than 1000 against both L1210 and $\mathrm{H}-125$. The activity of this fraction (FB) retain consistent at dilution of 1/4096 against $\mathrm{H} 116$ and $\mathrm{H}-125$ with zone of inhibition 700 and 1000 respectively. The fraction FB also showed significant inhibition at very dilution 1/16384 against $\mathrm{H}-125$ (Table 2). For the reason of significant inhibition of fraction FB against these cell lines especially against $\mathrm{H} 116$ and $\mathrm{H}-125$, the fraction FB were subjected to column chromatography, as a result the compound ficusonolide (1) was identified.

Ficusonolide (1) was tested against twelve cancer cell lines (Table 3). Interestingly, Ficusonolide (1) was also found active against two H116 cells (Human colon adrenocarcinoma) and H125 cells (Human lung adrenocarcinoma) with $\mathrm{IC}_{50}$ values 7.8 and $11.0 \mu \mathrm{g} / \mathrm{mL}$ respectively. The activity results of compound $\mathbf{1}$ were quite consistent with the trend observed for crude fraction FB from which leaded to the isolation of compound 1 . The literature survey for the comparison and structure activity relationship did not show same activity for other lactones with similar skeleton.

\section{Conclusions}

The bioassay guided chemical investigation of the Ficus faveolata stem resulted in the isolation of a new compound $1 ; 3 \alpha$-hydroxylean12-en-29,19 $\alpha$-olide (Ficusonolide). All the crude methanolic fractions (FA, FB, FC, FD and FE) and pure compound $\mathbf{1}$ were screened for their cytotoxic activity against six and twelve cancer cell lines respectively. The selectivity and potency of the pure compound $\mathbf{1}$ were in harmony with the activity profile of the fraction FB and ethno medicinal uses of this plant. This small project on local medicinal plants has opened new vista for future research work on indigenous medicinal plants.

\section{Acknowledgement}

This work was financially supported by Higher Education Commission (HEC) of Pakistan. We would like to thank Mr. Ambara khan for taxonomic identification plant and university of California Santa Cruz, USA for their help in providing research facilities.

\section{References}

1. Woodland DW (1997) Comtemporary Plants Systematic (2ndedn.), Andrews University Press, Barrien Springs, MI, USA.

2. Kislev ME, Hatmann A, Bar-Yosef O (2006) Early domesticated fig in the Jordan Valley. Science 312: 1372-1374. 
Citation: Din AU, Uddin G, Hussain N, Khan A, Khan I, et al. (2013) Bioassay-guided Isolation of New Antitumor Agent from Ficus faveolata (Wall. ex Miq.). J Cancer Sci Ther 5: 404-408. doi:10.4172/1948-5956.1000233

3. Lansky EP, Paavilaine HM, Pawlus AD, Newman RA (2008) Ficus spp. (fig): Ethnobotany and potential as anticancer and anti-inflammatory agents. Journal of Ethnopharmacology 119: 195-213.

4. Ahmed W, Khan AQ, Malik A (1988) Two triterpenes from the leaves of Ficus carica. Planta med 54: 481.

5. Teixeira DM, Patao RF, Coelho AV, da Costa CT (2006) Comparison between sample disruption method and solid-liquid extraction (SLE) to extract phenolic compounds from Ficus carica leaves. J Chromatogr A 1103: 22-28.

6. Chiang YM, Chang JY, Kuo CC, Chang CY, Kuo YH (2005) Cytotoxic triterpenes from the ariel roots of Ficus microcarpa. Phytochemistry 66: 495-501.

7. Chaudhary LB, Sudhakar JV, Kumar A, Bajpai O, Tiwari R, et al. (2012) Synopsis of the genus Ficus L. (Moraceae) in India. Taiwania 57: 193-216.

8. Kunwar RM, Bussmann RW (2006) Ficus (Fig) species in Nepal: a review of diversity and indigenous uses, Lyonia 11: 85-97.

9. Suksri S, Premcharoen S, Thawatphan C, Sangthongprow S (2005) Ethnobotany in Bung Khong Long Non-Hunting Area. Northeast Thailand, J Kasetsart (Nat Sci) 39: 519-533.
10. Sermboonpaisarn T, Sawasdee $P$ (2012) Potent and selective butyrylcholinesterase inhibitors from Ficus foveolata. Fitoterapia 83: 780-784.

11. Somwong P, Suttisri R, Baukeaw A (2013) New sesquiterpenes and phenolic compound from Ficus foveolata. Fitoterapia 85: 1-7.

12. Hoffmann H, Pan J, McLaughlin MS, Pierreiones AD (2002) Solid Tumor Selective Pyranoisoflavones and Other Cytotoxic Constituents from Antheroporum pierrei. J Exp Ther Oncol 2: 228-236.

13. Bruning R, Wagner $H(1978)$ Übersicht über die celastraceen-inhaltsstoffe: Chemie, chemotaxonomie, biosynthese, pharmakologie. Phytochemistry 17: 1821-1858.

14. De Fatima Silva DG, Duarte PL, De Silva Paes $C H$, De Sousa RJ, Nonato $\mathrm{CM}$, et al. (1998) 3-Epiabruslactone A, a new triterpene lactone isolated from Austroplenckia populnea. J Braz Chem Soc 5: 461-464.

15. Subramanian B, Nakeff A, Tenney K, Crews P, Gunatilaka L, et al. (2006) A new paradigm for the development of anticancer agents from natural products. J Exp Ther Oncol 5: 195-204. 